\title{
Author Correction: Blinatumomab in pediatric patients with relapsed/refractory acute lymphoblastic leukemia: results of the RIALTO trial, an expanded access study
}

Franco Locatelli, Gerhard Zugmaier (D), Noemi Mergen, Peter Bader, Sima Jeha, Paul-Gerhardt Schlegel, Jean-Pierre Bourquin, Rupert Handgretinger, Benoit Brethon, Claudia Rossig and Christiane Chen-Santel

Correction to: Blood Cancer Journal https://doi.org/10.1038/s41408-020-00342-x published online 24 July 2020

The original version of the article contained an error in Fig. 1b, which showed that 57/69 (78.3\%) of patients with
$\mathrm{CR}$ in the first 2 cycles achieved MRD response. The article has now been corrected to state 57/69 (82.6\%).

Published online: 01 February 2021
B

All patients with CR in first 2 cycles
Baseline blast category
$<5 \%$
$\geq 5-50 \%$
$250 \%$
Prior relapses
0
1
$\geq 2$
Prior HSCT
No
Yes

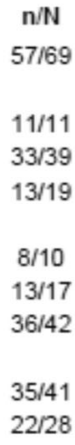

$35 / 41$

$22 / 28$
MRD response \%

$(95 \% \mathrm{Cl})$

$82.6(66.7-87.3)$

$100(71.5-100.0)$

$84.6(69.5-94.1)$

$68.4(43.4-87.4)$

80 (44.4-97.5)

76.5 (50.1-93.2)

85.7 (71.5-94.6)

$85.4(70.8-94.4)$

$78.6(59.0-91.7)$

Fig. 1

(c) Open Access This article is licensed under a Creative Commons Attribution 4.0 International License, which permits use, sharing, adaptation, distribution and reproduction in any medium or format, as long as you give appropriate credit to the original author(s) and the source, provide a link to the Creative Commons license, and indicate if changes were made. The images or other third party material in this article are included in the article's Creative Commons license, unless indicated otherwise in a credit line to the material. If material is not included in the article's Creative Commons license and your intended use is not permitted by statutory regulation or exceeds the permitted use, you will need to obtain permission directly from the copyright holder. To view a copy of this license, visit http://creativecommons.org/licenses/by/4.0/. 